\title{
POTENSI INTERAKSI OBAT RESEP PASIEN HIPERTENSI DI SALAH SATU RUMAH SAKIT PEMERINTAH DI KOTA SAMARINDA
}

\author{
Risna Agustina, Nurul Annisa, Wisnu Cahyo Prabowo \\ Fakultas Farmasi Universitas Mulawarman, Samarinda, Indonesia \\ *email: aaisyahrisna@yahoo.com
}

\begin{abstract}
Degenerative disease is a disease arising from the process of body cells function decline with age, one of which is hypertension. In the treatment of advanced stages of hypertension for many complications so the potential for very large polypharmacy is causing the possibility of drug-drug interactions. In this study conducted a study to determine the potential drug-drug interactions. Checking is done through www.drugs.comdatabase. This study describes the percentage of this type of polypharmacy and potential drug-drug interactions based on pre-defined levels. Of the total 290 prescriptions of hypertension, there are $17(5.86 \%)$ prescription sheet the number $1 \mathrm{R} /$ which means on the prescription sheet does not have the potential for drugdrug interactions and is not included in the category of polypharmacy, amounted to 147 $(50.69 \%)$ recipe sheet included in the category of minor polypharmacy and the number of $126(43.45 \%)$ prescription sheet in the category of major polypharmacy. While the number of sheets of recipes containing more than $1 \mathrm{R} /$ is a number of $273(94.14 \%)$ prescription sheet with the average number of $\mathrm{R} /$ on each sheet of 4 . Of the overall recipe is a recipe sheet that has the potential drug-drug interactions, potential total what happens is 183 interaction with the details, minor interaction by $66(22.75 \%)$ of interaction, interaction moderate at $99(34.13 \%)$ interactions, and interactions major by $18(6.21 \%)$ interaction.
\end{abstract}

Keywords : Drug-drug interactio, polypharmacy, hypertension.

\begin{abstract}
ABSTRAK
Penyakit degeneratif merupakan suatu penyakit yang muncul akibat proses kemunduran fungsi sel tubuh seiring bertambahnya usia, salah satunya adalah hipertensi. Pada pengobatan penyakit hipertensi untuk stadium lanjut banyak terjadi komplikasi sehingga potensi terjadinya polifarmasi sangat besar yang menyebabkan kemungkinan terjadinya interaksi obat-obat. Dalam penelitian ini dilakukan studi untuk mengetahui potensial interaksi obat-obat. Pengecekan dilakukan melalui www.drugs.comdatabase. Penelitian ini memaparkan persentase dari jenis polifarmasi dan potensi interaksi obat-obat berdasarkan tingkatan yang telah ditetapkan. Dari total 290 resep hipertensi tersebut, terdapat $17(5,86 \%)$ lembar resep dengan jumlah $1 \mathrm{R} /$ yang artinya pada lembar resep tersebut tidak memiliki potensi terjadinya interaksi obat-obat dan tidak termasuk dalam kategori polifarmasi, sebesar $147(50,69 \%)$ lembar resep termasuk dalam kategori polifarmasi minor dan sejumlah $126(43,45 \%)$ lembar resep masuk dalam kategori polifarmasi mayor. Sedangkan jumlah lembar resep yang mengandung lebih dari $1 \mathrm{R} /$ yaitu sejumlah $273(94,14 \%)$ lembar resep dengan rata-rata jumlah R/ pada setiap lembar resep adalah 4. Dari keseluruhan lembar resep yang memiliki potensi interaksi
\end{abstract}


obat-obat, total potensial yang terjadi adalah 183 interaksi dengan rincian, interaksi minor sebesar 66(22,75\%) interaksi, interaksi moderat sebesar $99(34,13 \%)$ interaksi, dan interaksi mayor sebesar $18(6,21 \%)$ interaksi.

Kata Kunci: Interaksi obat-obat, polifarmasi, hipertensi.

\section{PENDAHULUAN}

Polifarmasi

meningkatkan resiko terjadinya interaksi obat-obat. Interaksi obat-obat atau yang biasa disingkat dengan DDIs (drug-drug interaction) didefinisikan sebagai modifikasi efek suatu obat akibat obat lain yang diberikan pada awalnya atau diberikan bersamaan atau bila dua atau lebih obat berinteraksi sehingga keefektifan atau toksisitas suatu obat atau lebih berubah ${ }^{8}$. Apoteker harus bertanggung jawab untuk memonitoring interaksi obat dan menginformasikan kepada dokter dan pasien tentang masalah yang mungkin terjadi terkait interaksi tersebut ${ }^{1}$.

Peresepan pada pasien hipertensi menjadi fokus pada penelitian ini. Hipertensi merupakan salah satu jenis penyakit degeneratif dan memiliki potensi yang besar untuk terjadinya komplikasi, sehingga potensi untuk mengalami polifarmasi sangat besar, dan bukan hanya polifarmasi tetapi penyakit degeneratif juga erat kaitannya dengan usia, dan kebanyakan penyakit hipertensi diderita pada usia dewasa dan geriatri, usia geriatri sendiri berada pada resiko yang signifikan untuk masalah terkait obat dan merupakan faktor resiko utama untuk DDIs $^{2,5}$. Interaksi obat-obat pada pasien hipertensi sangat penting untuk diidentifikasi karena penggunaan obatobatannya dalam jangka waktu yang cukup panjang dan memiliki pengaruh terhadap goal terapi yang diharapkan, sehingga berpengaruh terhadap efektifitas pengobatan.

Potensi interaksi obat-obat merupkan hal yang penting untuk diidentifikasi dalam kegiatan kefarmasian di Rumah Sakit sehingga penelitian potensi interaksi obat-obat perlu dilakukan pada pasien rawat inap hipertensi di salah satu rumah sakit pemerintah yang berada di kota Samarinda.

\section{METODE PENELITIAN}

Penelitian ini merupakan penelitian deskriptif evaluatif dengan penelusuran data secara retrospektif terhadap rekam medik, penelitian ini dilaksanakan disalah satu rumah sakit pemerintah di kota Samarinda. Data yang digunakan merupakan data rekam medik periode Januari-juli 2015 dengan jumlah total 139 rekam medik. Sampel penelitian ini adalah pasien yang menjalani rawat inap dengan diagnosa utama hipertensi. Kriteria inklusi yaitu pasien dengan diagnosa utama hipertensi, pasin yang menjalani rawat inap $>24$ jam, pasien dengan usia $\geq 18$ tahun, dan memiliki catatan rekam medik yang lengkap. Sedangkan untuk kriteria ekslusi adalah hipertensi yang disebabkan oleh shock, ibu hamil, dan pasien dengan catatan rekam medik yang tidak lengkap. Tahap identifikasi potensi DDIs diidentifikasi menggunakan drugs.com database setiap harinya selama subjek penelitian dirawat inap ${ }^{3}$. Data dianalisis berdasarkan variabel yang sudah dikumpulkan dan kemudian dibuat tabulasi.

\section{HASIL DAN PEMBAHASAN}

Penelusuran data dilakukan dengan jalan mengamati satu persatu kartu rekam medik pasien. Untuk kasus hipertensi secara keseluruhan periode Januari-Juli 2015 dengan total jumlah 139 rekam medik. Pada penelusuran 
data ini didapatkan 65 responden. pasien hipertensi dengan jenis kelamin perempuan memiliki jumlah lebih banyak yaitu sebesar $65 \%$ dibandingkan laki-laki yaitu sebesar 35\%. Hal ini diduga bahwa kemungkinan perempuan lebih mudah stres dibandingkan dengan laki-laki. Stres berhubungan dengan hipertensi melalui saraf simpatis yang meningkatkan tekanan darah ${ }^{6}$. Hormon epinefrin atau adrenalin akan dilepas pada keadaan tertekan. Adrenalin akan meningkatkan tekanan darah melalui kontraksi arteri (vasokontriksi) dan peningkatan denyut jantung dengan demikian orang akan mengalami peningkatan tekanan darah. Selain itu, wanita berumur diatas 40 tahun akan mengalami menopause yang menyebabkan hormon esterogen menurun. Penurunan hormon esterogen dapat meningkatkan tekanan darah karena esterogen berperan melawan hipertensi melalui penghambatan jalur vasokontriktor oleh sistem saraf simpatik dan angiotensin ${ }^{4}$. Pasien lakilaki yang menderita hipertensi lebih banyak pada rentang usia 41-60 tahun yaitu sebesar 27,69\%. Hal tersebut terjadi karena angka harapan hidup yang kecil, sehingga populasi pasien dengan usia $>60$ tahun sedikit. Sedangkan usia>40 tahun banyak diderita oleh pasien perempuan yaitu sebesar 30,76\%. Hal ini disebabkan oleh penurunan elastisitas arteri. Penelitian Heryudarini menyatakan bahwa setiap peningkatan usia 1 tahun akan meningkatkan tekanan sistol sebesar 0,493 mmHg dan tekanan darah diastol sebesar 0,189 $\mathrm{mmHg}$. Semakin tua seseorang maka arteri akan kehilangan elastisitasnya yang menyebabkan kemampuan memompa darah berkurang sehingga tekanan darah meningkat ${ }^{4}$. Data karakteristik pasien hipertensi yang menjalani rawat inap dapat dilihat pada tabel 1 .

Tabel 1. Data karakteristik Pasien Hipertensi

\begin{tabular}{cccc}
\hline \multirow{2}{*}{ No. } & Rentang Usia & \multicolumn{2}{c}{ Jenis Kelamin } \\
\cline { 3 - 4 } & & Laki-Laki & Perempuan \\
\hline 1 & $18-40$ & $3,07 \%$ & $3,07 \%$ \\
2 & $41-60$ & $27,69 \%$ & $30,76 \%$ \\
3 & $>60$ & $4,615 \%$ & $30,76 \%$ \\
4 & Jumlah & $35 \%$ & $65 \%$ \\
\hline
\end{tabular}

Polifarmasi diklasifikasikan kedalam 2 kelas berdasarkan jumlah obat yang terdapat dalam tiap lembar resep. Lama rata-rata rawat inap pasien hipertensi adalah selama 5 hari dengan jumlah order resep 4 hingga 5 kali selama rawat inap tersebut. polifarmasi minor adalah adalah lembar resep yang mengandung 2-4 jumlah obat, sedangkan polifarmasi mayor adalah lembar resep yang mengandung $\geq 5$ jumlah obat ${ }^{10}$. Dari total 290 lembar resep yang masuk memiliki rata-rata jumlah R/ pada setiap lembar resep sejumlah 4. Hanya terdapat $17(5,86 \%)$ lembar resep yang terdiri dari $1 \mathrm{R} /$, hasil identifikasi klasifikasi polifarmasi dari tiap resep yang masuk adalah sejumlah $50,65 \%$ atau sejumlah 147 lembar resep dan polifarmasi mayor sejumlah $43,45 \%$ atau sejumlah 126 lembar resep. Hal ini menunjukkan bahwa sekitar 94,14\% lembar resep memiliki kemungkinan terjadinya interaksi pada tiap lembar resepnya. Hal ini tentunya menjadi kewajiban tenaga kesehatan untuk mewaspadai serta memberi 
perhatian lebih terhadap kasus polifarmasi yang terjadi.

Klasifikasi interaksi dibagi menjadi tiga kelompok yaitu interaksi minor, moderat dan mayor. Inteaksi minor adalah interaksi yang masih dalam tolerir karena jika ditemukan dalam lembar resep maka dalam terapi tidak perlukan adanya perubahan, interaksi moderat adalah interaksi yang mungkin terjadi dalam terapi dan memerlukan perhatian medis, sedangkan pengertian dari interaksi mayor adalah interaksi antar obat yang dapat menimbulkan konsekuensi klinis hingga kematian ${ }^{7}$. Sebanyak 183 lembar resep mengandung potensi interaksi obat-obat atau sejumlah 63\%, jika potensi tersebut di persentasikan kembali berdasarkan klasifikasinya terhadap jumlah keseluruhan potensi interaksi obat-obat maka didapatkan hasil dengan klasifikasi yaitu, interaksi minor sejumlah $36,07 \%$, interaksi moderat sejumlah $54,1 \%$, dan interaksi mayor sejumlah $0,84 \%$, maka dapat disimpulkan potensi interaksi yang terbesar pada lembar resep pasien hipertensi adalah potensi interaksi klasifikasi moderat, sehingga hal ini menuntut kewaspadaan dari tenaga kefarmasian dan dokter untuk mencegah atau meminimalisasi kejadian tersebut untuk meningkatkan kualitas pengobatan pasien, hasil kajian DDIs ini dapat dilihat pada tabel 2.

Tabel 2. Kajian Potensi Interaksi Obat (DDIs) Berdasarkan Klasifikasi Interaksi

\begin{tabular}{|c|c|c|c|c|c|c|c|}
\hline \multirow{2}{*}{$\begin{array}{l}\text { Rata-rata } \\
\text { lama rawat } \\
\text { inap }\end{array}$} & \multirow{2}{*}{$\begin{array}{l}\text { Rata-rata } \\
\text { jumlah } \\
\text { order obat }\end{array}$} & \multirow{2}{*}{$\begin{array}{c}\text { Jumlah } \\
\text { R/ }\end{array}$} & \multicolumn{3}{|c|}{$D D I s$} & \multicolumn{2}{|c|}{$\begin{array}{l}\% \text { Kejadian } \\
\text { Polifarmasi }\end{array}$} \\
\hline & & & Minor & Moderat & Mayor & Minor & Mayor \\
\hline 5 hari & 1 & 4 & $22,75 \%$ & $34,13 \%$ & $6,21 \%$ & $50,69 \%$ & $43,45 \%$ \\
\hline \multicolumn{4}{|c|}{ Total Potensi DDIs } & \multicolumn{4}{|c|}{$63 \%$} \\
\hline
\end{tabular}

Interaksi obat-obat banyak terjadi pada peresepan pasien hipertensi, hal ini mungkin dikarenakan jenis obat yang digunakan pada pengobatan hipertensi beragam, sehingga penggunaan kombinasi dari obat-obat tersebut tidak mudah untuk teridentifikasi, untuk memudahkan dalam pengecekkan interaksi antar obatobat ada baiknya pada apotek tiap instalasi di rumah sakit dilengkapi dengan software interaction checkers.

Penyakit degeneratif seperti hipertensi biasanya selalu diikuti dengan komplikasi penyakit pada organ lain seiring dengan lama perjalanan penyakit dan tingkat keparahannya, sehingga hal tersebutlah yang menyebabkan banyaknya kasus polifarmasi dalam tiap lembar resep.
Interaksi yang terjadi dapat berupa interaksi farmakokinetik dan farmakodinamik. Interaksi farmakodinamik pada usia $\geq 40$ tahun dapat menyebabkan respon reseptor obat dan target organ berubah, sehingga sensitivitas terhadap efek obat menjadi lain, yang akan berakibat pada besar dosis yang diresepkan ${ }^{12}$. Interaksi obat menjadi hal yang penting untuk diperhatikan apabila secara klinis dapat meningkatkan toksisitas atau menurunkan efek terapi dari obat tersebut, hal ini dapat diperkecil potensinya dengan cara menghindari penggunaan polifarmasi yang tidak dibutuhkan ${ }^{11}$.

Praktek farmasi klinis juga dapat memastikan bahwa kejadian efek samping obat dapat diminimalkan 
dengan menghindari obat dengan potensi efek samping pada kelompokkelompok pasien berisiko tinggi. Dengan demikian peran tenaga kefarmasian memiliki peranan yang cukup besar dalam pengendalian, pencegahan, deteksi dan pelaporan efek samping obat ${ }^{9}$. Beberapa interaksi obat dapat berakibat sangat berbahaya pada pasien hipertensi karena dapat berdampak pada nilai goal terapi tekanan darah yang diharapkan, contohnya pada penggunaan bisoprolol yang bersamaan dengan asam mefenamat akan mengakibatkan berkurangnya efek bisoprolol dalam menurunkan tekanan darah terutama jika penggunaan asam mefenamat digunakan secara rutin (misalnya, untuk mengobati nyeri kronis) karena asam mefenamat dapat menyebabkan terjadinya retensi cairan yang juga akan mempengaruhi tekanan darah ${ }^{3}$. Interaksi obat walaupun harus diwaspadai karena efek yang tidak dikehendaki tetapi ada beberapa interaksi yang sengaja karena mekanisme yang sudah diketahui dan untuk mengoptimalkan efektifitas dari proses pengobatan.

Keterbatasan pada studi ini adalah kurang banyaknya sampel yang didapatkan dan periode yang cukup singkat dalam pengambilan datanya, selanjutnya dapat dilakukan studi lanjutan dengan cakupan populasi dan sampel yang lebir besar dan dalam periode waktu yang lebih lama sehingga hasil penelitian dapat menggambarkan kondisi yang terjadi dilapangan dengan lebih baik. Namun penelitian ini sudah cukup menunjukkan fenomena peresepan yang terjadi pada pasien rawat inap hipertensi di salah satu rumah sakit pemerintah di kota Samarinda.

\section{KESIMPULAN}

Berdasarkan hasil dari penelitian ini maka dapat disimpulkan bahwa pasien hipertensi yang menjalani rawat inap di salah satu rumah sakit pemerintah yang ada di kota Samarinda berisiko mendapatkan potensial interaksi obat-obat (DDIs). Dari total 290 resep hipertensi tersebut, terdapat sebesar $147(50,69 \%)$ lembar resep termasuk dalam kategori polifarmasi minor dan sejumlah $126 \quad(43,45 \%)$ lembar resep masuk dalam kategori polifarmasi mayor . Dari keseluruhan lembar resep yang memiliki potensi interaksi obat-obat, total potensial interaksi obat-obat yang terjadi adalah 183 interaksi dengan rincian, interaksi minor sebesar $66(22,75 \%)$ interaksi, interaksi moderat sebesar $99(34,13 \%)$ interaksi, dan interaksi mayor sebesar $18(6,21 \%)$ interaksi.

\section{DAFTAR PUSTAKA}

1. Ansari, JA. Drug Interaction and Pharmacist. Journal of Young Pharmacist,2010, 2(3): 326-331.

2. Bjerrum L, Andersen M, Petersen G, Krangstrup J. Exposure to Potential Drug Interaction in Primary Health Care. Scan dinavian Journal Primary Health Care, 2003 21: 153-158.

3. Drug Interaction Checker. Cherner Multum, IncDenver, CO. http://www.drugs.com/. Diakses 2 Oktober 2015.

4. Dwi, Sri Handayani., Rolan, Rusli dan Arsyik, Ibrahim. 2015. Analisis Karateristik dan Kejadian Drug Related Problems pada Pasien Hipertensi di Puskesmas Temindung Samarinda. Jurnal Sains dan Kesehatan Vol 1 No. 2 hal 75-81.

5. Frazier SC. Health outcomes and polypharmacy in individuals: an integrated literature review. Journal of Gerontological Nursing, 2005, 31(9): 4.

6. Ganda, Sigalingging. 2011. Karateristik Penderita Hipertensi di Rumah Sakit Umum Herna Medan 2011.Hal. 1-6 Universitas Darma Agung: Medan.

7. Hansten PD, Horn JR. Drug interactions and update. 7 th ed. WA 
Aplied Therapeutics Inc: Vancouver. 2009.

8. Merle L, Laroche ML, Dantoine T, Charmes JP. Predicting and preventing adverse drug reaction in the very old. Drugs and Aging, 2005,22(5): 375-392.Kanus Kesehatan.Definisi Interaksi Obat. http://kamuskesehatan.com/arti/ interaksi obat/. Diakses pada 4 Oktober 2015.

9. Palanisamy S, Arul Kumaran KS, Rajasekaran A. A study on assessment, monitoring, documentation and reporting of adverse drug reaction at a multyspecialty tertiary care teaching hospital in South India. International
Journal Pharmacy Technology

Research, 2009, 4(3) : 1519-1522.

10. Reamer LB, Massey EB, SimpsonTW, Simpson KN. Polypharmacy: misleading, but manageable. Clinical Intervensions in Aging, 2008, 3(2) : 383- 389.

11. Sundborn LT. Women and men report deferent behaviours in and reason for medication nonadherence: a nationwide Swedish survey. Journal of Pharmacy Practice, 2012 10(4): 207-221.

12. Zhou X. Herb-drug interaction with Danshen: a review on the role of cytochrome P450 enzymes. Journal of Drug Interaction and Drug Metabolism, 2012, 27(1): 9-18. 